\title{
Use of castor oil polyurethane in an alternative technique for medial patella surgical correction in $\operatorname{dogs}{ }^{1}$
}

\author{
Utilização do poliuretano de mamona em técnica alternativa de correção cirúrgica da \\ luxação medial de patela em cães
}

\author{
Fabrício de Oliveira Frazilio ${ }^{2}$, Rafael de Rossi ${ }^{3}$, João Marcelino Negrini Neto ${ }^{4}$, Gilberto Gonçalves FaccoI ${ }^{5}$, Thalles \\ Monteiro Ovando ${ }^{6}$, Maria Paula Ferreira Fialho ${ }^{7}$ \\ 1. Postgraduate Program in Health and Development in the West Central Region - Federal University of Mato Grosso do Sul, (UFMS), Mato \\ Grosso do Sul, Brazil. \\ 2. Fellow Master Degree in Post Graduate in Health and Development in the West Central Region, UFMS, Brazil. \\ 3. PhD, Associate Professor of the Department of Veterinary, UFMS, Brazil \\ 4. MD Veterinarian, Brazil. \\ 5. Master, Assistant Professor of Division of Pathology of University for Development of the State and the Pantanal Region (UNIDERP), Brazil. \\ 6. Master, Assistant Professor of Division of Veterinary of University for Development of the State and the Pantanal Region (UNIDERP), Brazil. \\ 7. Fellow Master Degree in Post Graduate Federal University of Minas Gerais (UFMG), Brazil.
}

\begin{abstract}
Purpose: Comparative morphologic study of utilization of castor oil polymer in dogs joints, as an alternative technique to autogenous graft, in surgical correction of medial patella luxation. Methods: Twelve adult dogs, of both sexes, were randomly allocated to two different groups of six animals each. Group I (biopolymer) consisted of the deepening of the right femoral troclea, with the implantation of the biopolymer prothesis, and compared to group II (control) which consisted of the conventional trocleoplastia technique with wedged cut of the left femoral troclea. The dogs were sacrified after 30 or 90 days and the anathomic peaces were analyzed macro and microscopically. Qui square and Wilcoxon tests were used for the statistic analyses of the results, considering probability of 5\%. Results: It was not observed bony integration on the castor oil polymer group. There was resorption of the graft along experimental period and absence of inflammatory cells in the studied periods. Conclusion: Castor oil polymer assisted cicatrisation process, was biocompatible without inflammation, and it can be used in joints as an alternative for bony filling.
\end{abstract}

Key-words: Biomaterials. Bone Grafts. Alloplastic Implant. Castor Oil Polymer. Dogs.

\section{RESUMO}

Objetivo: Estudo morfológico do implante da prótese de polímero de mamona em articulações de cães, como técnica alternativa ao enxerto ósseo autógeno na correção cirúrgica da luxação medial de patela. Métodos: Doze cães adultos, de ambos os sexos, foram distribuídos aleatoriamente em dois grupos de 6 animais. No grupo I (poliuretano) - foi feito o aprofundamento da tróclea femoral direita com prótese de polímero de mamona, que foi comparado com o grupo II (controle) - sendo feita a trocleoplastia por ressecção em cunha da tróclea femoral esquerda. Os animais foram sacrificados após 30 e 90 dias e as peças anatômicas foram avaliadas macro e microscopicamente. O teste do quiquadrado e o teste nãoparamétrico de Wilcoxon foram utilizados para a análise estatística dos resultados. Fixou-se em 5\%, o nível de rejeição da hipótese de nulidade. Resultados: Não foi observada interação óssea (osteointegração) no grupo polímero de mamona. Houve reabsorção do enxerto ao longo do período experimental e ausência de células inflamatórias nos períodos analisados. Conclusão: O polímero de mamona auxiliou no processo cicatricial, foi biocompatível sem presença de inflamação, podendo ser usado em articulações como uma alternativa para o preenchimento ósseo.

Descritores: Biomateriais. Enxertos Ósseos. Implantes Aloplásticos. Polímero de Mamona.Cães.

\section{Introduction}

The osseous tissue, beyond its mechanic properties, presents a great spontaneous regeneration ability. Nevertheless, this capacity is limited, such the autogenous bone is still the ideal material for the repair of extensive osseous damages ${ }^{1,2}$. The finding of new polymers and copolymers has meaningfully contributed for the evolution of biomaterials utilization. From biomaterials, the by-product of castor bean (Ricinus comunis) oil is extremely interesting to Brazil, a country with great agro-industrial potential ${ }^{3}$. The castor oil polymer may be used pure or associated with calcium carbonate ${ }^{4}$. The carbonate works as a provider of calcium ions, facilitating the ionic changes at bone-resin interface, stimulating the mechanism of calcium deposition at the collagen matrix, in every step of osseous reparation process $^{4-6}$. Traumas, infections and congenital deformations are among the mainly causes of bone tissue losts. 
Oftentimes, a graft is needed so that the bones get completely reclaimed. Nowadays, castor oil polymer is one of the materials that is available for this kind of procedure, it was developed in Brazil and has been used in humans for 12 years. Pelvic limb disfunction, proceeding of patella medial luxation, is one of the great orthopedic problems in small breed dogs veterinarian clinic ${ }^{7}$, and is featured by the medial displacement of patella from its normal position at femoral troclea. Its etiology may be traumatic or congenital ${ }^{8}$. The correction of patella medial luxation may be done by conservatory or surgical conduct, depending on the clinical history, clinical signs and age of animal ${ }^{9,10}$, body weight, existence of degenerative disease and the degree of the luxation ${ }^{11}$, it may be considered that the surgical treatment does't assure the stunt the evolution of osteo-arthritis ${ }^{12}$. Surgical correction consists of the relining of the extensor mechanism and stabilization of patella at femoral troclea by the reconstruction of bone and other tissues ${ }^{10,13}$. New technique must be developed to restore the normal function of the limb and prevent or inhibit the progression of osteoarthritis ${ }^{14}$. Surgical correction doesn't stunt the development of osteo-arthritis, even in initial grade, nevertheless, improves limb's function ${ }^{15-17}$. Because of the great interest in biomaterials as an alternative to bony defects fill, this study has the purpose of evaluating the castor oil polymer action during bony neo-formation in joints.

\section{Methods}

This experiment was approved by the Ethic Comission of Animal Utilization (CEUA) from the Federal University of Mato Grosso do Sul, (UFMS), so that it agrees with the ethic principles of Brazilian College of Animal Experimentation. Twelve adult dogs, from both sexes, aging 1 to 2 years and averaging 15 kilograms $(\mathrm{kg})$ of body weight were provided from Control Center of Zoonoses from Campo Grande - MS township. Before the insertion in the experiment, dogs were submitted to biochemical exams, haemogram and search of anterior diseases, with the purpose of evaluating its general health. Animals were kept in Veterinary Medicine and Zoothecnics College of Federal University of Mato Grosso do Sul, during the hole experimental period. Dogs were randomly allocated to two different groups with 6 animals each one. The groups were divided into another two sub-groups consisting of four dogs each one, considering the time of histologic avaliation, 30 or 90 days, called: GI-30, GI-90, GII-30 e GII-90. Group I (polymer) - deepening of the right femoral troclea, with the implantation of the biopolymer prothesis. Group II (control) - conventional trocleoplastia technique with wedged cut of the left femoral troclea. Polymer prothesis were prepared with a mix of $20 \mathrm{ml}$ of polyol (liquid fraction 1) and $20 \mathrm{ml}$ of the pre-polymer (liquid fraction 2), $20 \mathrm{~g}$ of calcium carbonate (powder), mixed for two minutes so that the product became homogeneous and creamy. Five minutes later, the product achieved the manipulable condition (biomaterial). After that, the biomaterial was pressed between two odontological use glass plaques soaked with liquid vaseline to avoid adherence. This plaques were aparted by two glass flakes measuring $3,00 \mathrm{~mm}$ in thickness and $10 \mathrm{~cm}$ in length, so that the polymer was uniform with $3,00 \mathrm{~mm}$ in thickness. After twenty minutes the material was completely polymerized and in solid condition. Using a scalpel $n^{\circ} 22$, the polymer was cutted into small blocks measuring 2,00 or $3,00 \mathrm{~cm}$ in length and $1,00 \mathrm{~cm}$ in broadness. This blocks were individually sterilized with ethylene oxide so that they could be used at the surgery process. The dogs were kept in jejun for 12 hours and received no watter for 3 hours before surgery (Massone, 2000), body weight was measured and annotated in protocols. As pre-surgery medication were used morphine $10 \mathrm{mg} / \mathrm{ml}$ in dosage $0,5 \mathrm{mg} / \mathrm{kg}$ of body weight and acepromazine $1 \%$ in dosage $0,05 \mathrm{mg} / \mathrm{kg}$ by intramuscular way in the posterior limb. After the vein puncture, through a scalp $\mathrm{n}^{\circ} 23$, and application of physiological serum $0,9 \%$ the animals received ketamine cloridratum $1,5 \mathrm{mg} / \mathrm{kg}$ and xilazine cloridratum $2 \%$ in dosage of $1 \mathrm{mg} / \mathrm{kg}$. It was realized the tricotomy and antisepsis using alcohol $70^{\circ} \mathrm{GL}$ and iodated alcohol $2 \%$ and then the sterile surgery rag. Surgical technique was based on the traditional technique and consists of the deepening of troclear surface keeping the hialin cartilage, called wedged cut trocleoplastia (Figure 1). A small saw is used in femoral troclea for the wedged cut in the shape of "V" (Figure 2). A bigger quantity of the subcondral bone is removed through additional saw cuts (Figure 3). Soon after, the removed articular wedge is relayed at an abased position (Figure 4). The pressure of patella and the friction of the graft and subcondral bone dispense the need of internal attachment. Castor oil polymer implant was based at the same technique described above, nevertheless, instead of replacing the articular wedge, the polymer filled in the scratched area. There was no need of internal attachment for the same reasons described before as well as for the objective of the experiment in observing the organism reaction to the biomaterial (Figure 5). Articular capsule was sutured in simple continuous pattern using poliglactin 910 n. 2.0 and the skin as simple interrupted pattern with nylon n. 2.0. immediately after surgery, dogs received $40.000 \mathrm{UI} / \mathrm{kg}$ body weight of crystalline benzilpenicillin 1.200.000 UI (single dose intramuscular) and no-steroidal anti-inflammatory based in meloxican dosed as $0,1 \mathrm{mg} / \mathrm{kg}$ each 24 hours for four days in subcutaneous way. For daily wound dressing it was used iodated alcohol $2 \%$ and animals movements were restricted to the kennel. Animals clinical evaluations were realized weakly for 30 days.

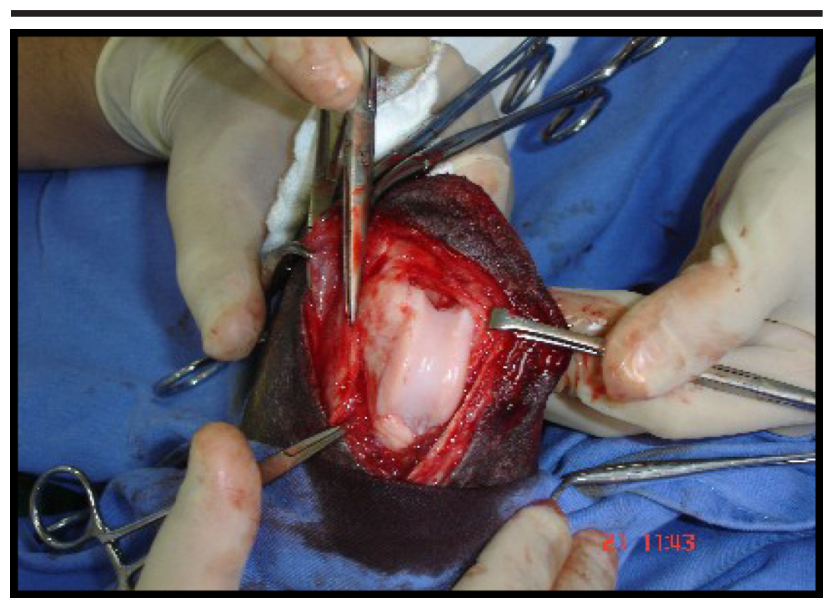

FIGURE 1 - Aperture of articular capsule. 


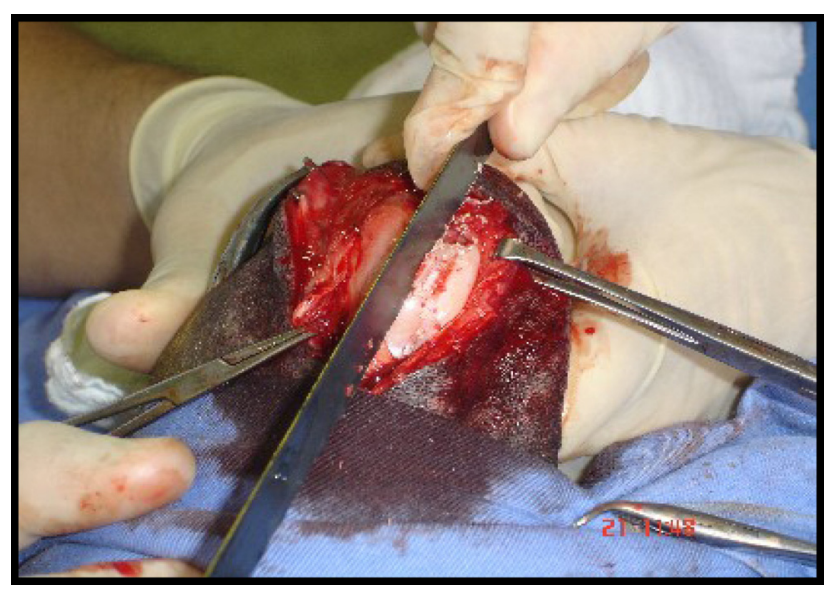

FIGURE 2 - Deepening of femoral troclear furrow using a saw.

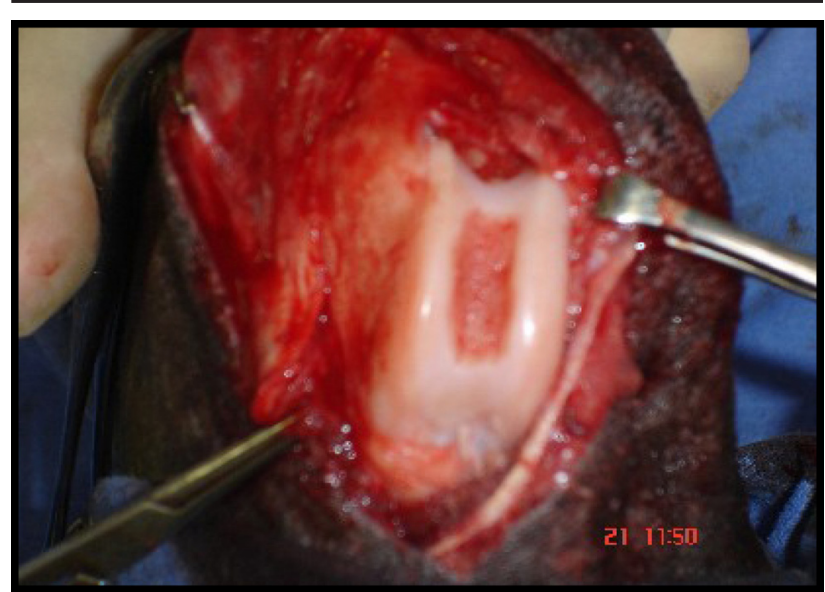

FIGURE 3 - Picture of femoral troclear furrow ready for the graft.

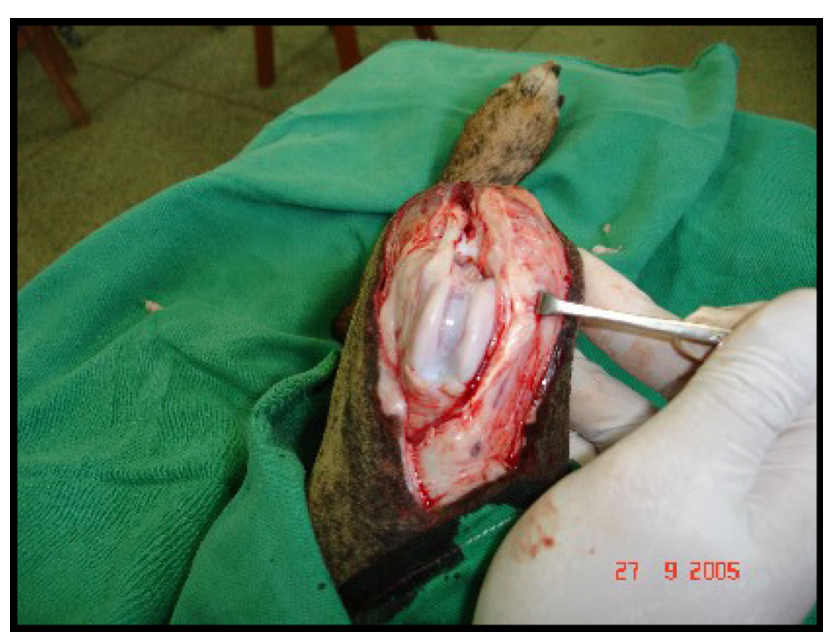

FIGURE 4 - Conventional technique of autogenous graft.

After 30 or 90 days of observation (sub-groups I and II, respectively), animals were submitted to the same anesthesia procedure of the surgery, followed by the collection of histo- pathological exam material. Qui square and Wilcoxon tests were used for the statistic analyses of the results, considering probability of 5\%.

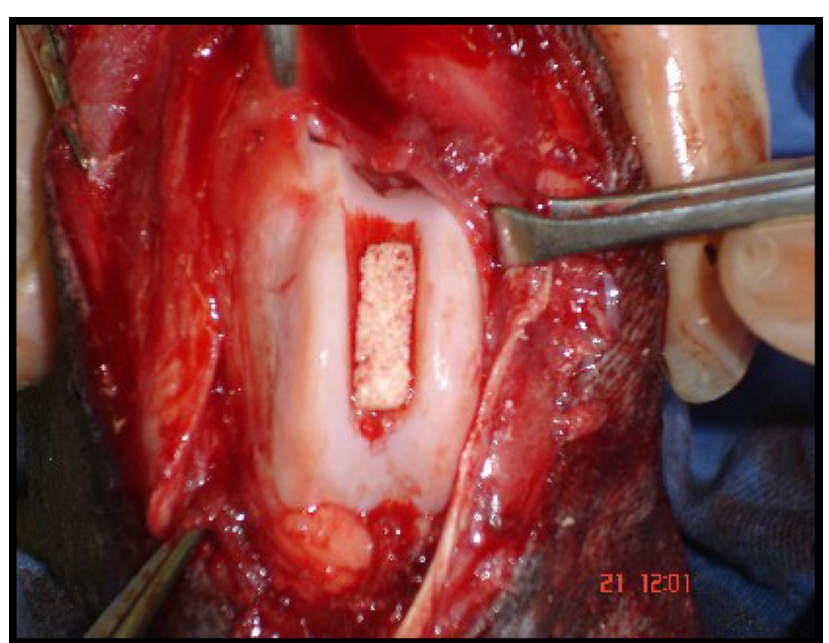

FIGURE 5 - Castor oil polymer implant at right posterior limb's femoral troclea

\section{Results}

The implants were well applied (Table 1), so that only one animal presented displacement of the castor oil polymer, probably due to other pathologies acquired during the experimental period.

TABLE 1 - Macroscopic observation of cator oil polymer or autogenous graft adaptation in troclear furrow of animals in group I (castor oil polymer) and II (autogenous graft).

\begin{tabular}{lcccc}
\hline Group & \multicolumn{3}{c}{ Adaptation } & \\
\cline { 2 - 3 } & Fitted & Unfitted & Total & $\%$ \\
\hline Polymer & 5 & 1 & 6 & $83,33^{*}$ \\
Autogenous & 6 & 0 & 6 & $100,00^{*}$ \\
\hline Total & 11 & 1 & 12 & 91,66 \\
\hline
\end{tabular}

*Meaningfull difference following quis quare test $(\mathrm{p}<0,05)$. $\mathrm{X}^{2}$ calculated $=1, \mathrm{X}^{2}$ table $=3,8$

Group II (control group) presented accentuated fibroblastic proliferation after 90 days and moderated after 30 days, with activated fibroblasts intensively active, showing oval and large nucleus with moderated angiogenesis. There was absence of inflammatory infiltrate and necrosis areas in sub-groups 30 and 90 days (Table 2). It was observed intense activity of condroblasts and bony trabeculas in cartilaginous tissue. In group I (implant with 30 days), histological sections showed fibroblastic proliferation areas with traces of capsule formation and presence of polymer with some bony trabeculas formation, bony and cartilaginous tissue around the implant. It was observed absence of inflammatory infiltrate, necrosis areas and presence of angiogenesis. Group I (implant with 90 days), histological sections showed accented areas of firoblastic proliferation and presence of connective tissue visualized with Trcrômio of Gomori (TG) coloration. Polyurethane graft was reduced with lots of bony trabeculas, with absence of infamatory infiltrated, necrosis areas and angiogenesis (Table 3 ). 
TABLE 2 - Semi-quantitative evaluation of histological paramethers after 30 and 90 days to determinate the effectiveness of castor oil polymer and autogenous bony graft

\begin{tabular}{lccccc}
\hline 30 days & \multicolumn{2}{c}{ Autogenous bony graft } & & \multicolumn{2}{c}{ Castor oil polymer } \\
\cline { 2 - 3 } \cline { 5 - 6 } & 30 days & 90 days & & 30 days & 90 days \\
\hline Angiogenesis & 1 & 2 & 1 & 2 \\
Inflammation & 0 & 0 & 0 & 0 \\
Fibroblastic proliferation & 2 & 3 & 1 & 3 \\
Necrosis & 0 & 0 & 0 & 0 \\
\hline
\end{tabular}

Score: $0=$ absentee; $1=$ light; $2=$ moderate; $3=$ accented

TABLE 3 - Histological paramethers evaluation as medium scores for animals in group I (castor oil polymer) after 30 and 90 days

\begin{tabular}{lcc}
\hline Castor oil polymer & 30 days & 90 days \\
\hline Inflammation & 0 & 0 \\
Capsule presence* & 0 & 3 \\
Trabecules formation* & 1 & 3 \\
Polymer presence* & 3 & 1 \\
Bony proliferation around the implant* & 1 & 2 \\
Fibroblastic proliferation* & 2 & 3 \\
\hline
\end{tabular}

Score: $0=$ absentee; $1=$ light; $2=$ moderate; $3=$ accented

*Different by non-paramethric Wilcoxon $(\mathrm{p}<0,05)$.

Histological parameters evaluation showed an increase in capsule presence, bony trabeculas formation, bony proliferation around the implant and fibroblastic proliferation in sub-group 90 days $(\mathrm{p}<0,05)$. There was a reduction in polymer presence at 90 days to $(\mathrm{p}<0,05)$. Microscopy evaluation showed, in group II (control) after 30 days, presence of bony trabecules and transition areas of autogenous graft (Figure 6), and connective tissue formation after 90 days (Figure 7). It was observed, at Group I (castor oil polymer) after 30 days, transition areas between the polymer and bony tissue and the existence of connective tissue (Figure 8), and after 90 days, connective tissue capsules using HE e TG (Figure 9 and 10) colorations, respectively.

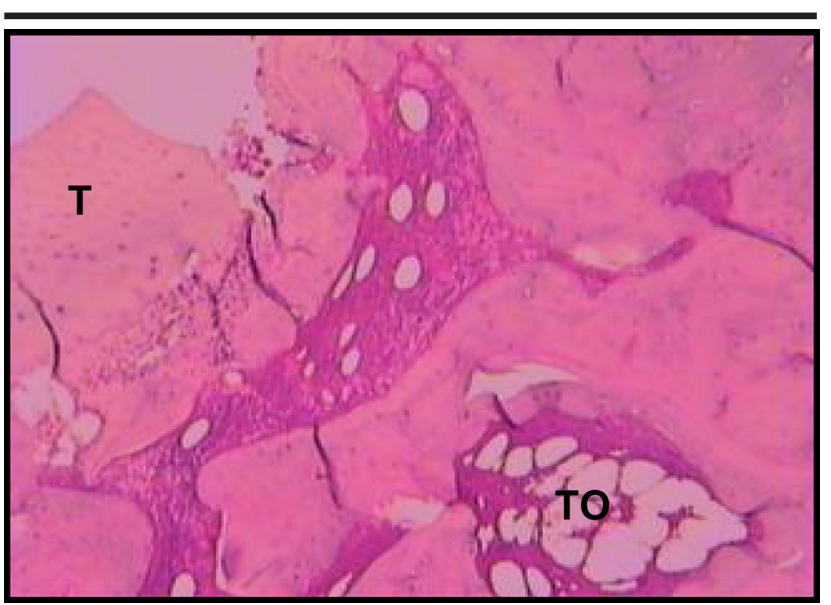

FIGURE 6 - Microscopic aspect of bony tissue in control group after 30 days showing bony trabecules (TO) and transition (T) area of autogenous graft. 5X increase. HE coloration

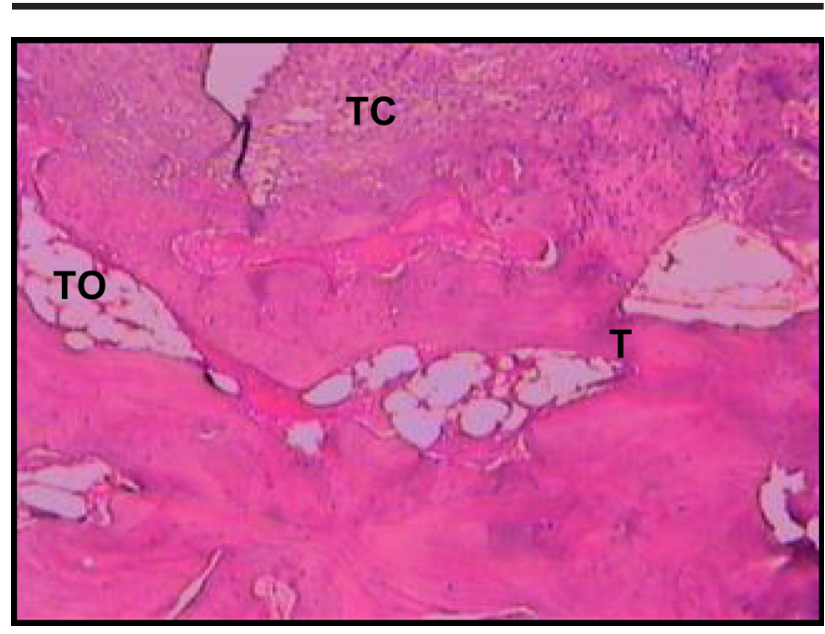

FIGURE 7 - Microscopic aspect of bony tissue of control group animals after 90 days, showing bony trabecules (TO), transition area (T) and connective tissue (TC). $5 \mathrm{X}$ increase. HE coloration

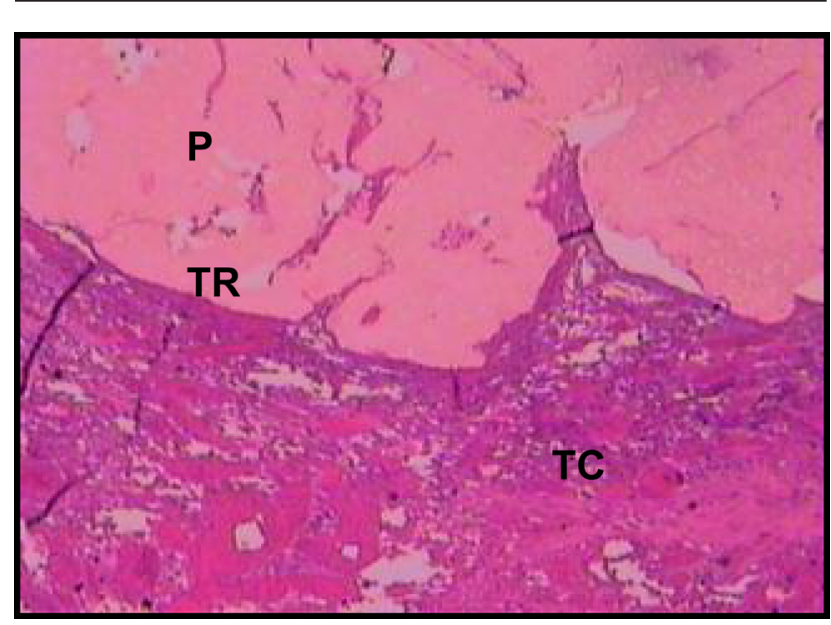

FIGURE 8 - Microscopic aspects of bony tissue of castor oil polymer group after 30 days, showing polymer graft $(\mathrm{P})$, transition area of polymer and bony tissue (TR) and connective tissue (TC). $5 \mathrm{X}$ increase. HE coloration 


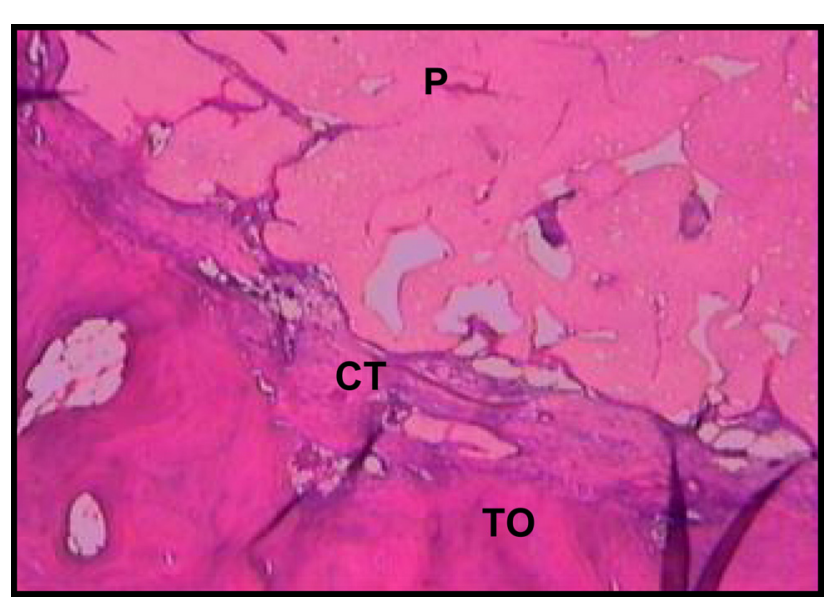

FIGURE 9 - Microscopic aspect of bony tissue of castor oil polymer group animals after 90 days, showing polymer graft $(\mathrm{P})$, bony tissue (TO), connective tissue capsule (CT). $5 \mathrm{X}$ increase. HE coloration

\section{Discussion}

Medial patella luxation treatment may be surgical or conservative, and the decision about which method will be used depends on the level of the lesion ${ }^{11}$. Surgical correction consists of realigning the extensor mechanism and stabilization of femoral patella in the troclea by the reconstruction of soft and bony tissues ${ }^{10,13}$. In many dogs, the success is achieved with the combination of tibial crest transposition, trocleoplastia technique with wedged cut and overlap of fáscia lata ${ }^{12}$. The techniques must be combined according to the severity of the lesion, bony deformity and surgeon preference ${ }^{9}$. According to Piermattei \& Flo $^{18}$, the most common cause of un-success is the difficult of transponding the tibial crest. Therefore, at this study, the surgical technique of wedged cut trocleoplastia was chosen because of the great interest of surgeons, so that it is actually the most used technique medial patella luxation correction in dogs. In this study, considering the identification of the prosthesis, macroscopic evaluation of the prosthesis showed that it was well fixed at every dog of control group and displaced in only one animal in the castor oil polymer group. Comparing both groups, the identification of the grafted material was significantly greater at castor oil polymer group, what can be due to slow resorption of the polymer that is of lipidic nature and is reabsorbed by lipolitic mechanisms. Chierici ${ }^{19}$ suggested, thru citoquimic studies, that the castor oil polymer is identified by the organism as a lipid. It would cause an enzymatic process which does not require the participation and, consequently, the presence of giant cells generated by inflammatory process, which is an undesirable tissue response for regeneration tissue process. Studies realized in rabbits showed that the prosthesis were easily displaced during the direct macroscopic exam, although the polymers were firmly adapted to the new bony boxing ${ }^{4,20}$. In this work the

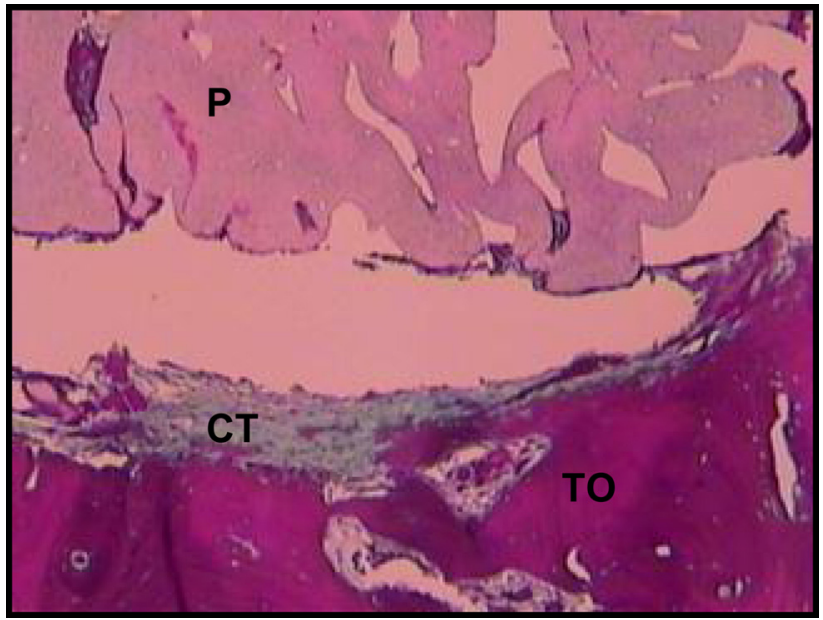

FIGURE 10 - Microscopic aspect of bony tissue of castor oil polymer graoup after 90 days, showing polymer graft (P), bony tissue (BT), connective tissue capsule (CT). $5 \mathrm{X}$ increase. Gomori tricromio coloration

prosthesis were not easily displaced, not at the control group nor at the polymer group. It probably happened because of the anatomic position of the implant, receiving the pressure of the patella, that was over it. Therefore, the preparation and application of the mixture in pre-molded prosthesis, as proposed in this study, conduced to the formation of a prosthesis that is easily molded when moistened in physiologic soluction, and is of easy adaptation in the bony failure, adapting without the need of fixing. Still in macroscopic evaluation, it was observed the absorption of the polymer without the substitution by new tissue. Ignácio ${ }^{20}$ e Maria ${ }^{17}$ observed corresponding results studying the use of castor oil polymer in dogs, without observing the bony-integration. Histopathologic exams confirmed the founds of Ignácio ${ }^{20}$, finding the presence of connective tissue recovering the castor oil polymer without its bony-integration. The absence of phenomenons corresponding to infectious or rejection process observed in our histopathological study, was expected, because corresponding results were observed in every species in what the polymer was tested ${ }^{4,6,20}$. This study demonstrated that autogenous graft or castor oil polymer can be used in joints with the presence of its constituents. All the animals had great recuperation after about 15 days of the surgery, being able to stand the limb on the ground. Autogenous graft is the mainly choice to correct levels I and II of patella luxation, in what there is no bony deformity, admitting the graft. Levels III and IV, in what there is tibial rotation and about $60^{\circ}$ to $90^{\circ}$ of medial displacement of its crest in anteroposterior plane, medial displacement of quadriceps muscle, deformities at femur distal piece and, when troclea becomes inexistent or even convex, polymer prosthesis is a good choice to correct the pathology. 


\section{Conclusion}

Castor oil polymer applied as prosthesis to surgical correction of patella medial luxation was biocompatible for the studied species, causing no kind of inflammatory reaction, necrosis areas or rejection from the innkeeper tissue, being bio-tolerant along the time, without bonyintegration.

\section{References}

1. Jacques JW. Estudo comparativo entre enxerto ósseo autógeno e poliuretana de mamona em coelhos [Dissertação - Mestrado]. Universidade Federal de São Paulo - Escola Paulista de Medicina; 2001.

2. Bôer HH. The history of bone grafts. Clin Orthop. 1988; 226:292-8

3. Ohara GH, Kojima KE, Rossi JC, Telles M, Soares T.V.C, Salomão C, Sandra M. Estudo experimental da biocompatibilidade do polímero poliuretano da mamona implantada intra-óssea e intra-articular em coelhos. Acta Orthop Bras. 1995; 3:62-8.

4. Ignácio H. Utilização do cimento derivado do polímero da mamona no preenchimento de falha óssea. Estudo experimental em coelhos [Dissertação - Mestrado]. Faculdade de Medicina de Ribeirão Preto da USP, 1995.

5. Fujiu T, Ogino M. Difference of bond bonding behavior among surface active glasses and sintered apatite. J Biomed Mater Res. 1984; 18: 845-59.

6. Berry JL, Geiger JM, Moran JM, Skraba JS, Greenwald AS. Use of tricalcium phosphate or eletrical stimulation to enhance the bone - porous implant interface. J Rheumatol. 1986; 20:1066-9.

7. Iamaguti P, Prado L, Del Carlo RJ, Vulcano LC, Mamprim MJ, Dal Pai V. Patelectomia e aprofundamento do sulco troclear no tratamento de luxação de patela. Estudo experimental em coelhos. Vet Zootec. 1995; 7:85-99.

8. Hulse DA. Pathophysiology and management of medial patellar luxation in the dog. Vet Med Small Anim Clin. 1981; 76:43-51.
9. Hulse DA. The Stifle Joint. In Olmstead M L. Small animal orthopedics. St. Louis: Mosby Year Book, 1995.

10. Vasseur HR. The stifle joint. In: Slatter D H. Textbook of small animal surgery. 2 ed. Philadelphia: W. B. Saunders. 1993.p.1854-1861.

11. Slatter M, Robinson LE, Hodges CC, Hulse DA. Longterm follow-up of dogs treated surgically for medial patellar luxation. Veterinary and Comparative Orthopedics and Traumatology, 1994.

12. Roush JK. Canine patellar luxation. Vet Clin North America: Small Animal Practice. 1993; 23:855-68.

13. Seguin B, Harari J. Trochlear wedge recession for the treatment of patellar luxation. Canine Practice. 1994;6:24-27.

14. Roy RG et al. A retrospective evaluation of stifle osteoarthritis in dogs with bilateral medial patellar luxation and unilateral surgical repair. Vet Surg. 1992;6:475-479.

15. Ferguson J. Patellar luxation in the dog and cat. In Practice. 1997;4:174-184.

16. Read RA. Opciones racionales de tratamiento de la luxación interna de rótula. Waltham Focus. 1999;4:25-31.

17. Maria PP. Emprego da poliuretana de mamona (Ricinus communis) aplicada em defeito ósseo produzido experimentalmente na porção proximal medial da tíbia no cão, para estudo do desvio da crista tibial. [Dissertação - Mestrado]. Jaboticabal: Faculdade de Ciências Agrárias e Veterinárias. Universidade Estadual Paulista. 2001.

18. Piermattei DL, FLO GL. The stifle joint. In: Handbook of small animal orthopedics and fracture repair. 3ed. Philadelphia: Saunders; 1997. p.516-581.

19. Chierice, GO. Pesquisa e desenvolvimento de biomateriais baseados em poliuretanas derivadas do óleo de mamona. SNM-PADCT-II; 1994 p. 76.

20. Ignácio H. Avaliação da poliuretana da mamona nas formas compacta e porosa no preenchimento de falha óssea: estudo experimental em cães [Tese - Doutorado]. Universidade de São Paulo-Faculdade de Medicina; 1999.

\section{Correspondence:}

Rua Alexandre Fleming, 1248 - Bloco B, Apto. 13

Vila Bandeirantes

79100-000 - Campo Grande - MS - Brazil

Phone: +55 67 3331-4319/+55 67 8404-2633

email: fabriciofrazilio@yahoo.com.br
Conflict of interest: none Finantial source: none

\section{How to cite this article:}

Frazilio FO, Rossi R, Negrini Neto JM, Facco GG, Ovando TM, Fialho MPF. Use of castor oil polyurethane in an alternative technique for medial patella surgical correction in dogs. Acta Cir Bras. [serial on the Internet] $2006 ; 21$ Suppl 4. Available from URL: http://www.scielo.br/acb. 